\title{
UTILIZATION OF GEOSPASIAL INFORMATION TO IMPROVE MAKING MAP SKILL IN GEOGRAPHY LEARNING
}

\author{
Dony Purnomo ${ }^{1}$ \\ ${ }^{1}$ SMAN 1 Purwantoro \\ Email : donypurnomo88@gmail.com
}

\begin{abstract}
The aim of this reseach are: (1) To describe the use of geospatial information in improving the skills of students in making maps, (2) To improve the skills of students in making maps. This class action research uses two cycles with research subjects in class XI IPS 4 at SMAN 1 Purwantoro academic year 2018/2019. The research method used is classroom action research. In the research the stages were carried out systematically in two cycles of action treatment and observation of one initial condition as a comparison after a cycle treatment. The indicator of success in this study is the classical completeness of students above $70 \%$ and there is an increase in student learning outcomes. The results of this study are (1) Utilization of geospatial information in improving map-making skills through several stages, namely introduction, gathering geospatial information, making maps, presentations, closing. (2) Utilization of geospatial information on geographic subjects can improve students' skills in making maps. Improvement of student learning outcomes is reflected in the percentage of classical completeness in the first cycle of $57.69 \%$ and in the second cycle rose to $88.46 \%$. While the average value in classical in the first cycle of 69.82 rose to 82.38 in cycle 2.
\end{abstract}

Keywords: Geospatial Information, Learning, Geography, Maps

\section{A. INTRODUCTION}

The development of information technology is growing rapidly. One of them is the development of geospatial information for geography learning. Utilization of geospatial information in geography learning provides convenience to students and teachers in accessing information to achieve learning goals. This is in line with the learning paradigm in the era of industrial revolution 4.0 which requires digital literacy as an analysis material, critical, creative, and innovative thinking.

The expected results from geography learning are students' spatial intelligence. Faiz (2016) describes spatial intelligence as

giving individuals the ability to determine orientation and mobilization. These abilities can be represented into three abilities, namely cognitive maps, cognitive collages, and mental spatial. These three capabilities represent the ability of humans to explore the surface of the earth by transforming various types of information obtained from the environment into spatial information. Lee (2011) explained that the indicators for measuring spatial thinking skills can be measured using STAT (Spatial Thinking Ability Test) which consists of eight aspects : (1) understanding orientation and direction, (2) comparing information on maps with 
graphical information, (3) choosing the best location based on spatial factors, (4) imagining slope profiles based on topographic maps, (5) correlating spatial distribution phenomena, (6) drawing threedimensional objects based on twodimensional information, (7) doing map overlays, and (8) understand the geographic appearance of points, lines and polygons.

The problem that is often faced in geography learning is the assumption in the minds of students that geography learning is rote learning. The impact of this assumption is that students race to memorize the material presented by the teacher. This assumption arises because the learning done by the teacher is theoretical, so it is less able to optimize the spatial intelligence of students. The result is the ability of students to study learning material has not led to spatial thinking.

Interest is important in the learning process. Slameto (2010: 57) explains that interest is a fixed tendency to pay attention and remember some activities. Interest is indeed very influential on someone. Interest is a person's likes and likes of an object. Students who are interested in learning will focus and have high curiosity during learning. With the interest of someone will do something that will produce something for someone (Siagian, 2015). This is because interest is a driving factor for students to learn continuously (Suharwati, 2016).
Furthermore, students' learning interest influences enthusiasm and activeness of students in the learning process. Students who have a high interest in learning always try to follow the learning process as well as possible to obtain optimal learning outcomes (Putrayasa, 2014).

Oktavianto (2017) explains the fundamental weakness of the spatial cognitive aspects is that there is no development of analytical knives that can be used to deal with spatial problems. A student can have a lot of knowledge about a place, but in another place, these students fail to carry out spatial analysis because what they have learned in the classroom is not in the form of spatial thinking skills, but only spatial knowledge.

Difficulties experienced by students in spatial thinking because of the lack of activity of students in producing products during the learning process, and the teacher does not use the media that can develop the cognitive abilities and skills of students. Students will be more interested if in learning, the teacher provides an opportunity for students to innovate and foster creativity.

To achieve the expected learning outcomes need the right learning media. Simanungkalit (2011) explains that the use of media accelerates and facilitates the achievement of learning objectives. In connection with that there are several principles that need to be considered in the 
selection of learning media: (1) the purpose and objective of selecting learning media, (2) characteristics of Learning Media, concerning, range, flexibility, media dependence, control, attributes and costs, (3) certain characteristics, both seen from its superiority, how to make and how to use it, and other alternative choices.

Maps is one of the characteristics in geography learning. Maps are representations or representations of abstract appearance elements selected from the surface of the earth that have to do with the surface of the earth or celestial bodies, which are generally depicted on a flat and scaled plane (International Cartographic Association, 2003). Whereas Bakosurtanal which is currently changing to BIG (2005) defines maps as a vehicle for storing and presenting data on environmental conditions, is a source of information for planners and decision makers at the stages and levels of development. Referring to the definition of the map, geography learning will be more meaningful if students can produce maps in the learning process.

Based on the initial survey on students, $57.69 \%$ of students have not been able to map properly. This shows that the ability to map students is still relatively low so efforts are needed to improve map-making skills so that they can further improve the spatial intelligence of students. Setiawan (2015) explained that spatial thinking is an important character in geography learning activities. The study of geographic phenomena not only explains the existence of a phenomenon and the process of the occurrence of this phenomenon on the surface of the earth but also the shape, size, direction, pattern of phenomena and the relation with other phenomena.

In the 2013 curriculum the geography subject competencies are formulated from the point of view of the relationship between human and environmental interaction systems in three dimensions. The geographic perspective on the dynamics of the physical environment and the community environment will be seen from the aspect of spatial integration and space interdependence both between places and between scales. This perspective can be manifested in real or abstract forms both visually, verbally, mathematically, digitally, as well as in mindset. With this, learning innovations are needed that are able to represent spatial phenomena in the form of maps so that they can change learning from abstract to concrete.

\section{B. MATERIALS AND METHODS}

The research method used is classroom action research. Setyosari (2010: 43) defines classroom action research as research that we can do in practical situations, with the intention of improving or improving practical situations. 
Tripp in Subyantoro (2012: 34) states that the class action research design includes four stages, namely: planning, action, observation, and reflection. In the research the stages were carried out systematically in two cycles of action treatment and observation of one initial condition as a comparison after a cycle treatment. The study was conducted in the XI IPS 4 class of SMAN 1 Purwantoro 2018/2019 academic year with 26 research subjects.

The data collected in this study is the skills of students in making maps and learning activities of students. While the data source is in the form of project results of the work of students, observation, questionnaires, documentation and interviews. The indicator of success in this study is the increase in students' skills in making maps, namely: (1) At least $70 \%$ of students complete in making maps in geography learning, (2) There is an increase in the average learning outcomes of students in learning to map.

\section{RESULTS AND DISCUSSION}

\section{Initial conditions}

Based on the assessment of learning outcomes regarding the skills of making maps in class XI IPS 4 is relatively low, $42.31 \%$ of students complete. Based on the results of interviews with students, it was concluded that they did not understand the essence of the actual map. In making map symbols, the main difficulties in drawing map symbols are still inaccurate in entering map data so that maps produced by students become less precise with applicable mapping rules. The difficulties faced by students are entering data related to nominal data and ordinal data, students still have difficulty in distinguishing the two data.

Based on the results of observations during learning, students pay less attention to the basic map used to make maps so that the resulting map becomes less precise. Most students get maps from downloading on the internet and do not pay attention to the scale contained in the map.

Based on these initial conditions, contextual data-based learning is needed and is easy for students to understand so that students become challenged in following the next lesson, causing motivation to map properly according to the applicable mapping rules.

\section{Cycle 1}

Based on the facts found in the initial conditions, then the action carried out in cycle 1 consisted of planning, carrying out activities, observing, reflecting. The action in cycle 1 was carried out in 2 meetings (4x45 minutes). The implementation of learning takes place through five stages, namely: (1) The teacher performs an apperception, (2) Learners explore various geospatial information related to the theme of the map to be created, (3) Students make 
maps based on the base map and information that has been collected, (4) Participants students present the results of map making and the results of map analysis, (5) closing activities.

Based on the results of observations in cycle 1 there are still students who have not been right in downloading maps assigned by the teacher. Errors experienced by students are carrying a map with incomplete information. So students must join other groups to make maps. In processing data, many students still experience errors in calculating the population of each region that will be made a map so that it must recalculate so that the data produced can be correct.

Based on the results of the assessment of maps that have been made by students, the results of $57.69 \%$ of students are completed in the practice of making maps and $42.31 \%$ of students have not yet finished making maps. Errors made by students are in making map symbols not paying attention to the data symbolized, mainly in color symbols. In making the map component also found errors in the depiction of map components that are not in accordance with the rules of drawing map components.

Based on the results of the implementation of the first cycle of indicators of learning success has not been achieved because students who complete the new learning reached $57.69 \%$ while the completeness criteria set is $70 \%$. The average class value obtained in cycle 1 is 69.82. From these results a second cycle is needed to achieve the learning success criteria that have been set.

After the implementation of cycle 1, a reflection is then carried out to find out the shortcomings in cycle 1 and then be corrected in cycle 2. Based on reflection on cycle 1 there are several things that must be corrected in cycle 2, namely: (1) Directing in choosing the correct base map to create derivative maps. (2) Use the Microsoft Excel application to process data. (3) Utilizing peer tutors for students who have not understood the material. (4) Geospatial information that is processed using actual information. (5) The area mapped by the students is taken from the area around the students.

\section{Cycle 2}

In the first cycle the success criteria for learning that have not been achieved are then followed by the second cycle. The steps taken in cycle 2 are the same as cycle 1 , namely through the stages of planning, implementation of activities, observation, reflection. The timing of the action in cycle 2 is the same as cycle 1 which is $4 \times 45$ minutes.

Based on the results of observations in cycle 2 there has been a change in the activities of students. Students are more active in learning. Peer tutoring activities 
also run by the way students who do not understand the material are explained and guided by students who have understood the material. In terms of processing data in cycle 2 it is also faster and reduces errors because it has used Microsoft Excel in processing the data. The selection of basic maps used by students is also correct so that the basic map used to create derivative maps has met the requirements. Data and maps made in cycle 2 are areas around students so that students are more enthusiastic in making maps. This is in accordance with the opinion of Joyce (2009) which explains that various abilities of students can be trained and improved in quality with a variety of structured activities by doing (do).

The results of the action in cycle 2 showed that $88.46 \%$ of students had completed learning in making maps while $11.54 \%$ of students had not yet completed learning to make maps. Based on the results of interviews with students who have not been completed, it can be concluded that students are less serious in participating in learning. The time given to make a map is not utilized as well as possible so that the maps made are not completed according to the target time given by the teacher. Furthermore, the three unfinished students were given additional learning outside the learning hours and students were given a different treatment, namely making maps at home so that more time was available. The class average value in cycle 2 increased by 8.90 to 78.72 . The increase is an indicator of success in the learning process in accordance with the provisions of the success of learning that has been set.

Based on the percentage of students' completeness and the increase in class average in cycle 2, learning in cycle 2 has fulfilled the criteria for success of the action so that it is not continued in the next cycle. Based on the results of the research, the skills in making maps in cycle 1 and cycle 2 have increased. The percentage of classical completeness in cycle 1 was $57.69 \%$ and in cycle 2 it increased to $88.46 \%$. While the average value in classical in cycle 1 is 69.82 up to 82.38 in cycle 2. Furthermore, the highest value achieved in cycle 1 is 73 in cycle 2 to 86 . The lowest value in cycle 1 is 56 in cycle 2 being 68 . The number of students who completed in the first cycle were 11 students while the ones that were not completed were 15 students, in the second cycle the students who had completed experienced an increase to 23 and which did not complete into 3 students, detail presented in the following diagram: 


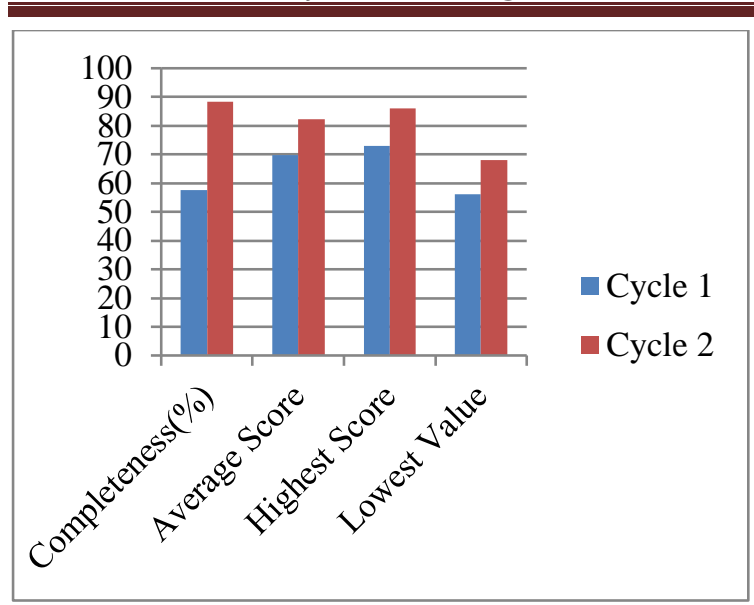

Figure 1. Graphs of Cycle 1 and 2 Increase

Based on the indicators of the success of learning that has been determined that is more than $70 \%$ of students complete in learning and the increase in student learning outcomes in the pre-cycle to cycle 2 , this classroom action research was declared successful. Learning by utilizing geospatial information requires guidance from the teacher in working on the project, so that students can do all stages of map making correctly and the basic map used is also correct. This is in accordance with the opinion of Trianto (2011) which explains that the learning model that has been well designed, but is not well guarded in the implementation process, is feared unable to achieve competency as expected / determined.

\section{CONCLUSIONS}

Based on the results of the research and discussion it can be concluded several things including the following: (1) Utilization of geospatial information in improving map- making skills through several stages, namely introduction, gathering geospatial information, making maps, presentations, closing. (2) Utilization of geospatial information on geographic subjects can improve students' skills in making maps. Improvement of student learning outcomes is reflected in the percentage of classical completeness in the first cycle of $57.69 \%$ and in the second cycle rose to $88.46 \%$. While the average value in classical in the first cycle of 69.82 rose to 82.38 in cycle 2 .

\section{E. REFERENCES}

Bakosurtanal. (2005). Badan Koordinasi Survey dan Pemetaan Nasional. Jakarta.

Faiz, Urfa. 2016. Pengaruh Lingkungan Sekolah Terhadap Kecerdasan Spasial Peserta Didik Melalui Affordance Dan Geoliteracy Menggunakan Analisis Jalur. Jurnal Pendidikan Geografi, Vol 6 No. 2 Tahun 2016. Hal. 105-115.

ICA. (2003). International Cartographic Association. Swedia.

Joyce, Bruce. 2009. Models of eaching: Advance Organizer. New Jersey: Pearson Education Inc.

Lee, Jongwon \& Bednarz, Robert. 2011. Components of spatial thinking: Evidence from a Spatial Thinking Ability Test. Journal of Geography, vol.3, No.1,pp 15-26.

Oktavianto, Dwi Angga. 2017. Pengaruh Pembelajaran Berbasis Proyek Berbantuan Google Earth Terhadap Keterampilan Berpikir Spasial. Banten: Jurnal Teknodik, Vol. 21 , No. 1, Juni 2017, hal. 59-69. 
Putrayasa, I Made. 2014. Pengaruh Model

Pembelajaran Discovery Learning Dan Minat Belajar Terhadap Hasil Belajar IPA Siswa, Bali: Jurnal Mimbar PGSD Universitas Pendidikan Ganesha, Vol. 2 No. 1 Tahun 2014.

Setiawan, Iwan. 2015. Peran Sistem Informasi Geografis (SIG) Dalam Meningkatkan Kemampuan Berpikir Spasial (Spatial Thinking), Bandung: Jurnal Pendidikan Geografi, Volume 15, No. 1, April 2015, hal.63-89.

Setyosari, Punaji. 2010. Metode Penelitian Pendidikan dan Pengembangan. Jakarta: Kencana Prenada Media Group

Siagian, Roida Eva Plora. 2015. Pengaruh Minat dan Kebiasaan Belajar Siswa Terhadap Prestasi Belajar Matematika. Jakarta: Jurnal
Formatif, Volume 2, No. 2, hal. 122131.

Simanungkalit, 2011. Pemilihan Media dan Cara Membuat Peta Statistik Untuk Pembelajaran Geografi di SMA. Medan: Jurnal Geografi, Volume 3 No. 2, hal. 67-82.

Slameto. 2010. Belajar dan Faktor- Faktor yang Mempengaruhinya. Jakarta: Rineka Cipta.

Subyantoro. 2012. Penelitian Tindakan Kelas. Semarang: Unnes Press

Suharwati, Sri Ira. 2016. Pengaruh Model Pembelajaran Resource Based Learning Terhadap Minat Dan Hasil Belajar Geografi Siswa SMA. Malang: Jurnal Pendidikan, Volume 1, No. 2 Bulan Februari 2016, hal 7479

Trianto. 2011. Mendesain Model Pembelajaran Progresif. Jakarta: Kencana Prenanda Media Group. 